\title{
KETERKAITAN ELEMEN INTERIOR TEMPAT MAKAN TERHADAP SOSIAL MASYARAKAT
}

\author{
Ivo Ramadhani \\ Program Studi Desain Interior Fakultas Seni dan Desain \\ Universitas Potensi Utama \\ Email:ivor205@gmail.com
}

\begin{abstract}
ABSTRAK
Tempat makan di Kota Medan semakin populer dilihat dari beberapa tahun terakhir ini. Banyak elemen-elemen interior yang menjadi fasilitas pendukung tempat makan tersebut. Penelitian ini memiliki tujuan untuk mengeksplorasi unsur-unsur lingkungan yang disukai oleh serta dapat mempengaruhi respon sosial masyarakat pada tempat makan tersebut. Penelitian ini menggunakan metode deskriptif eksploratif untuk menentukan variabel yang dapat digunakan sebagai stimulus eksperimen berikutnya guna mendapatkan respon persepsi, emosi, dan sikap kemudian data hasil eksperimen dianalisis menggunakan ANOVA (Analisis of Variance), menunjukkan bahwa elemen interior yang paling mempengaruhi sosial masyarakat pada tempat makan tersebut; meskipun gaya modern dapat membangkitkan respon sosial persepsi, emosi, elemen dekoratif dan furniture yang paling efektif; ditemukan juga hubungan antara persepsi, emosi, dan sikap kaitannya dengan proses persepsi, emosi dapat mempengaruhi sikap masyarakat pada tempat makan, hal ini sejalan dengan mekanisme persepsi dimana kontribusi sosial dapat membangkitkan emosi sehingga mempengaruhi persepsi dan munculnya sikap masyarakat pada tempat makan tersebut.
\end{abstract}

Kata kunci : elemen interior; sosial masyarakat; tempat makan.

\begin{abstract}
Places to eat in the city of Medan are increasingly popular seen from the last few years. Many interior elements are the supporting facilities for the eating place. This study aims to explore the environmental elements that are liked by and can influence the social response of the community to the eating place. This study uses descriptive exploratory methods to determine the variables that can be used as the next experimental stimulus in order to get perceptual responses, emotions, and attitudes then the experimental data are analyzed using ANOVA (Analysis of Variance), indicating that the interior elements most influence people's social eating place the said; although the modern style can generate the most effective social responses to perception, emotion, decorative elements and furniture; also found the relationship between perception, emotions, and attitudes related to the process of perception, emotions can influence people's attitudes to places to eat, this is in line with the perception mechanism where social contributions can arouse emotions that affect the perception and appearance of the attitude of the community in the eating place.
\end{abstract}

Keywords: interior elements, social community, places to eat 


\section{PENDAHULUAN}

Desain ruang tempat makan merupakan salah satu faktor pendukung nilai jual dan daya tarik masyarakat untuk mengunjungi tempat tersebut guna mendapatkan kesan yang baru, disamping itu juga perlu adanya penataan yang terkait dengan elemen-elemen tata ruang baik dari segi fungsi maupun dari segi estetika. Desain ruang dapat menciptakan suasana untuk menonjolkan suatu identitas dari makanan dan pelayanan yang disuguhkan guna menghasilkan kesan makan yang menarik agar dapat mendorong pelanggan merasakan kenyamanan sehingga mreka akan membagikan pengalaman makan yang mengesankan dan akan mempengaruhi tingkat sosial masyarakat. Pengalaman menimbulkan kekuatan pendorong dalam menciptakan kesan dibanyak bagian dunia saat ini. Dalam perilaku konsumen, pengalaman diaplikasikan sebagai bagian dari pandangan konsumsi barang dan makanan, serta membutuhkan stimulus, kehadiran artefak, gambar, narasi yang memiliki hubungan positif dengan masa lalu. Berdasarkan penjelasan tersebut, desain ruang tempat makan dapat menghasilkan pengalaman yang berkesan bagi konsumen, serta penerapan dari elemen desain ruangan sudah banyak diterapkan dalam era modern saat ini, contohnya Ismud Park, Cafe Tip Top, Lekker Urban Food House, Desa-desa resto dan lainnya.

Kota Medan merupakan salah satu kota tujuan wisata di Indonesia yang disematkan sebagai Kota Metropolitan terbesar ketiga di Indonesia dengan ragam etnis sebagai ciri khasnya serta terdapat banyak tempat rekreasi alam dan bahkan kuliner. Kota Medan juga berkembang dalam sektor kuliner sehinggan banyak terdapat pusat-pusat konsumsi makanan yang menjadi bagian penting dalam budaya urban masa kini. Dengan demikian mindset yang ada dalam masyarakat mengalami pergeseran nilai terhadap kebutuhan dasar menjadi pengalaman yang lebih mengesankan.

Menurut Rahma.MS.dkk, dalam penelitian sebelumnya "(exploratory factor analysis) mengindikasikan bahwa pengalaman konsumen dipicu oleh empat faktor, yaitu: 'makanan', 'event', 'lingkungan', dan 'karyawan'. Penelitian tersebut memperlihatkan bahwa sebuah tempat memiliki kemampuan memicu emosi pengalaman yang dapat menjadi motif kuat konsumen pertama kali memilih tempat. Komponen emosi berperan penting bagi sebuah tempat makan dalam membentuk image dan pengalaman konsumen. Berdasarkan uraian tersebut penelitian ini bertujuan untuk mengungkap variabel elemen interior tempat makan manakah yang paling berpengaruh membangkitkan pengalaman yang mencakup persepsi dari segi emosi dan sikap positif untuk berpengalaman.

Menurut Widagdo (2001), seperti yang dikutip oleh F.S. Paul, menjelaskan bahwa "seorang desain interior dilihat sudah melupakan tugas-tugas budaya, hal ini terjadi karena para desainer saling bersaing menghasilkan rancangan interior yang baik dan unik demi menarik masyarakat, sehingga pertimbangan-pertimbangan komersial, sensasi visual, menjadi sangat mengedepan perannya" (Widagdo, 2001:1). Sedangkan yang terpenting dalam sebuah perancangan interior adalah menciptakan suasana dan perlambang lingkungan sosial yang mengisyaratkan bahwa perwujudan estetika interior harus menyangkut nilai-nilai umum, gagasan-gagasan empirik, filosofis, norma-norma moral, keyakinan ideologi, kondisi ekonomi, teknologi dan lain-lain (Suptandar, 1999:43). Pada hakekatnya hal ini disebabkan karena arsitektur merupakan ruang dengan perwujudan dari suatu konsepsi kehidupan yang berkaitan dengan lingkungan sosial, jadi terlihat bahwa 
ruang dalam arsitektur mempunyai kaitan yang erat sekali dengan lingkungan dan kebudayaan dimana ruang itu berada. Ruang dalam asitektur memiliki kaitan yang erat terhadap lingkungan dan kebudayaan yang dimana ruang tersebut berada dengan memberitahukan adanya suatu interaksi dan hal tersebutlah yang mulai terlupakan oleh para desainer interior khususnya tempat makan.

\section{STUDI LITERATUR}

\section{II.I. Pengertian Desain Interior}

Menurut D.K. Ching (2002:46), desain interior adalah sebuah perencanaan tata letak dan perancangan ruang dalam pada dalam bangunan. Keadaan fisiknya memenuhi kebutuhan dasar akan naungan dan perlindungan serta mempengaruhi bentuk aktivitas dan memenuhi aspirasi dan mengekspresikan gagasan yang menyertai tindakan, disamping itu sebuah desain interior juga mempengaruhi pandangan, suasana hati dan kepribadian. Oleh karena itu tujuan dari perancangan interior adalah pengembangan fungsi, pengayaan estetis dan peningkatan psikologi ruang interior.

\section{II.II. Elemen Dasar Interior}

Elemen dasar interior merupakan elemen yang selalu digunakan pada setiap banguna ruangan, adapun elemen dasar interior tersebut yaitu :

\section{Plafon}

Plafon adalah langit-langit rumah yang terletak di bawah atap dan berada di atas lantai. Salah satu fungsi plafon yaitu sebagai tanambah estetika ruangan, hal ini dikarenakan konstruksi pada plafon dapat dibuat berbagai macam bentuk.

\section{Dinding}

Dinding merupakan salah satu elemen bangunan yang berfungsi memisahkan atau membentuk ruang. Jika ditinjau dari segi struktur dan konstruksi, jenis dinding ada yang berupa dinding yang berjenis partisi atau pengisi (tidak menahan beban) dan ada yang berupa jenis dinding struktural (bearing wall). Dinding pengisi atau partisi yang sifatnya non struktural harus diperkuat dengan rangka (untuk kayu) dan kolom praktis-sloof-ringbalk (untuk bata). Jenis- jenis dinding dapat dibuat dari bermacam-macam material yang sesuai dengan kebutuhannya, diantaranya yaitu :

a. Dinding batu buatan : bata dan batako

b. Dinding batu alam/ batu kali

c. Dinding kayu: kayu log/ batang, papan dan sirap

d. Dinding beton (struktural - dinding geser, pengisi - clayding wall atau beton pra cetak)

\section{Lantai}

Lantai merupakan bagian dasar sebuah ruang, yang memiliki peran penting untuk memperkuat eksistensi obyek yang berada di dalam ruang. Adapun salah satu fungsi dari lantai yaitu dapat sebagai media unsur pendukung memperindah ruang dan membentuk karakter ruang interior.

\section{Furnitur}


Furnitur merupakan istilah yang dipakai untuk perabot rumah tangga dan memiliki fungsi sebagai tempat penyimpan barang, tempat duduk, tempat tidur, tempat mengerjakan sesuatu dalam bentuk meja atau tempat menaruh barang di permukaannya.

\section{Pewarnaan}

Penjelasan warna yaitu kesan yang diperoleh mata melalui cahaya pantulan dari benda-benda yang dikenainya (Departemen Pendidikan Nasional, 2008: 1617). Warna juga dianggap sedikit banyak menentukan karakter. Warna dapat memberikan ekspresi kepada pikiran dan jiwa manusia yang melihat dan merasakannya. Maka dari itu, sedikit banyak melalui warna juga dapat menentukan karakter serta dapat menjadi sarana yang mempengaruhi keadaan manusia dalam berbagai perasaan dan emosi. Secara tersendiri, warna mampu mengangkat mood dan meningkatkan energi, menenangkan, rileks, serta mampu meningkatkan atau menurunkan selera seseorang. Penggunaan warna untuk penataan ruang dalam sebuah bangunan tidak terlepas dari fungsi bangunan serta fungsi ruangan di dalamnya. Tujuan pewarnaan interior tidak hanya terbatas untuk sekedar menyenangkan mata saja, tetapi mempunya tujuan lain, misalnya untuk peningkatan efisien kerja, penyembuhan dan mengundang selera.

Idarmadi Kosam (2006: 360) menguraikan karakter dari warna, berikut tabel karakter warna.

Tabel 1. Karakter Warna menurut Idarmadi Kosam (2006)

\begin{tabular}{|c|c|c|}
\hline NO & WARNA & KARAKTER \\
\hline 1. & Merah & $\begin{array}{l}\text { Power, energi, kehangatan, cinta, nafsu, agresif, } \\
\text { bahaya. }\end{array}$ \\
\hline 2. & Biru & $\begin{array}{l}\text { Kepercayaan. Konservatif, keamanan, teknologi, } \\
\text { kebersihan, keteraturan. }\end{array}$ \\
\hline 3. & Hijau & Alami, sehat, keberuntungan, pembaharuan. \\
\hline 4. & Kuning & $\begin{array}{l}\text { Optimis, harapan, filosofi, ketidakjujuran, pengecut } \\
\text { (untuk budaya barat), penghianatan. }\end{array}$ \\
\hline 5. & Ungu & $\begin{array}{l}\text { Spiritual, misteri, kebangsawanan, transformasi, } \\
\text { kekasaran, keangkuhan. }\end{array}$ \\
\hline 6. & Oranye & Energi, keseimbangan, kehangatan. \\
\hline 7. & Coklat & Tanah / bumi, realibility, comfort, daya tahan. \\
\hline 8. & Abu-abu & $\begin{array}{l}\text { Intelek, masa depan (seperti warna milinium), } \\
\text { kesederhanaan, kesedihan. }\end{array}$ \\
\hline 9. & Putih & $\begin{array}{l}\text { Kesucian, kebersihan, ketepatan, ketidaksalahan, steril, } \\
\text { kematian. }\end{array}$ \\
\hline 10 & Hitam & $\begin{array}{l}\text { Power, seksualitas, kecanggihan, kematian, misteri, } \\
\text { ketakutan, kesedihan, keanggunan. }\end{array}$ \\
\hline
\end{tabular}

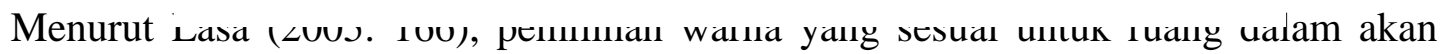
memberi kesan: a. Suasana yang menyenangkan dan menarik

b. Secara tidak langsung dapat meningkatkan semangat dan gairah kerja. Dengan demikian diharapkan akan mampu meningkatkan produktifitas kerja. 


\section{c. Mengurangi kelelahan}

\section{Sirkulasi udara/Penghawaan}

Sirkulasi udara atau ventilasi alami akan terjadi jika terdapat perbedaan tekanan antara lingkungan luar dengan ruang dalam suatu bangunan, yang disebabkan oleh angin atau perbedaan temperatur. Pengudaraan alami dalam rumah tinggal juga perlu direncanakan.

\section{Penerangan}

Tujuan utama pencahayaan adalah untuk meningkatkan fungsi dari ruangan itu sendiri, karena pencahayaan merupakan salah satu unsur penting dalam sebuah gedung atau bangunan. Faktor yang menentukan berhasil tidaknya perencanaan pencahayaan di dalam ruangan tergantung dari kondisi bangunan itu sendiri.

\section{II.III. Perilaku Manusia Mempersepsi Lingkungan}

Perilaku dan sikap manusia tidak lepas dari bagaimana manusia mempersepsi lingkungan serta informasi yang ada pada sekitarnya berupa elemen fisik ataupun nonfisik yang merupakan stimulus luar yang diterima melalui kelima panca indera kemudian diamati, diolah, dan diinterpretasikan sehingga menghasilkan persepsi, emosi, sikap ataupun perilaku sebagai respon manusia. Persepsi merupakan proses ketika individu memilih, mengorganisasi dan menginterpretasi sebuah sensasi (sesuatu yang merangsang emosi). Persepsi merupakan bagian terpenting dalam membantu pembuatan keputusan baik sikap atau perilaku individu dan pada objek benda (lingkungan fisik) maupun objek sosial akan melalui perseptual yang sama. Proses kerja persepsi terdiri dari proses sensorik berupa penerimaan stimulus melalui alat indera dan proses psikologik yang merupakan proses kerja otak yang terdiri dari beberapa rangkaian peristiwa di mana proses pemberian makna lingkungan dipengaruhi oleh pengalaman masa lalu.

Kontribusi sosial masyarakat dalam proses persepsi terhadap persepsi akan mempengaruhi kognisi yang memungkinkan terjadinya persepsi, motivasi, sikap dan perilaku yang muncul sesuai dengan penjelasan Litterer dalam Nimpoeno dalam Budiarti. Sikap masyarakat seperti membeli ataupun re - visiting dapat dipicu dengan cara memancing memori masyaraka.. Holak dan Havlena dalam Rutherford menyatakan bahwa tenderness, irritation, elation, loss, fear, and serenity merupakan enam faktor emosional yang cenderung dikaitkan dengan pengalaman sosial individu dipersepsi sebagai emosi yang positif berupa kehangatan dan sukacita. Sejak stimulus (informasi, data,dan lainnya) diterima oleh panca indera kemudian masuk ke dalam sistem kognisi, akan mengikuti sistem pengorganisasian yang sama. Terdapat tiga variabel yang dapat mempengaruhi prasangka, yaitu;

(1) Variabel fisik berupa bentuk, ukuran, posisi, kontras, frekuensi, warna, serta elemen indrawi;

(2) situasi berupa stimulus lingkungan fisik atau sosial;

(3) Variabel orang, latar belakang, pengalaman, lingkungan sosial, cara berpikir, jenis kelamin, usia, asumsi, minat dan keadaan individu merupakan faktor alami yang dapat mempengaruhi persepsi. 


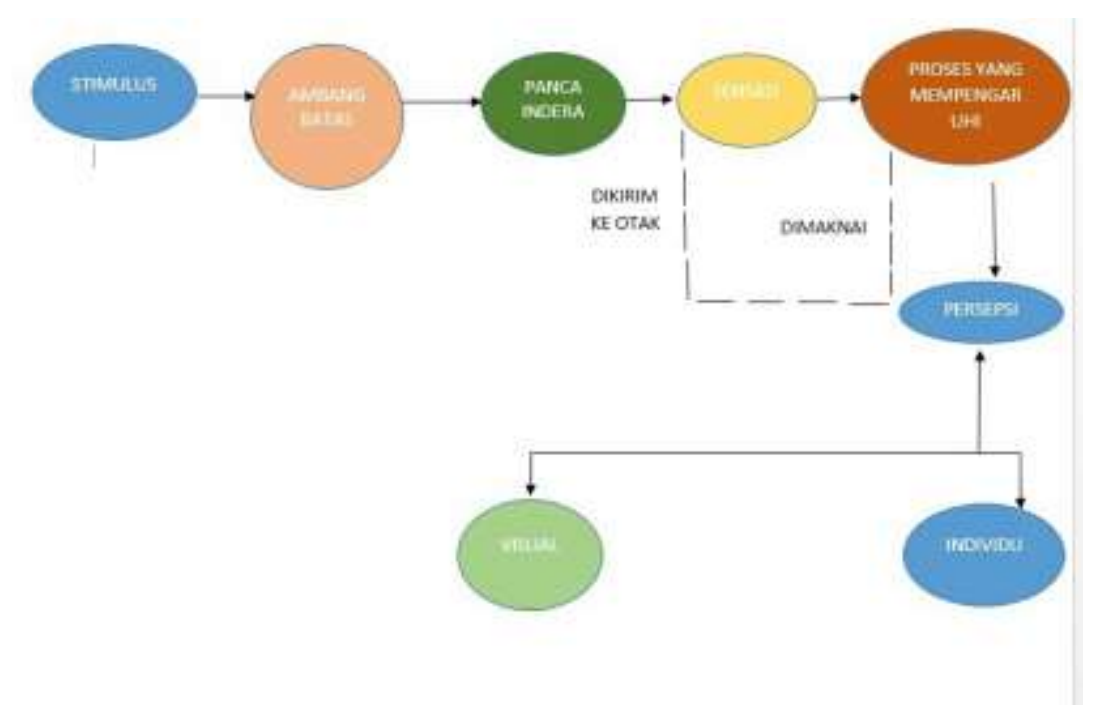

Gambar 1. Alur proses persepsi.

(Sumber : https://andisaputri26.files.wordpress.com, 2015)

Lingkungan dapat memberikan dampak psikologi individu dan stimulus lingkungan dapat mempengaruhi emosi individu mengakibatkan perilaku yang beranekaragam. Keputusan masyarakat saat membeli di beberapa tempat cenderung disebabkan karena suasana dibandingkan produk atau makanan yang ditawarkan, keselarasan antara tangible dengan intangible dapat dicapai melalui penampilan fisik seperti makanan dan wine yang dikombinasikan dengan interior tempat makan (struktur fisik dan artefak). Atmosfer yang didalamnya terdiri dari temperatur, pencahayaan, aroma, dan suara secara langsung berkontribusi dalam menciptakan pengalaman makan. Elemen interior merupakan salah satu faktor utama dalam menciptakan suasana tempat makan sehingga dapat mendorong pengunjung untuk berlama-lama dan datang kembali hingga merekomendasikan kepada orang lain. Dengan kata lain dapat disimpulkan bahwa adanya hubungan antara lingkungan fisik dengan perilaku, perasaan dan persepsi pengunjung. Dengan adanya rangsangan yang diterima oleh alat indera, individu dapat menginterpretasikan suasana tempat makan melalui proses persepsi mempengaruhi emosi berikutnya dapat mempengaruhi sikap individu.

\section{II.2. Keterkaitan Elemen Interior Tempat Makan dengan Sosial Masyarakat}

Suasana tempat makan dibutuh kan untuk menarik pengunjung berkunjung, karena secara psikologis pengunjung dapat merasakan karakter sebuah tempat makan tersebut. Suasana merupakan gambaran dari efek gabungan pengunjung terhadap lingkungan (keadaan ruang) dengan persahaan (restoran) berdasarkan kondisi psikologisnya. Terdapat dua bagian elemen interior yang perlu diperhatikan, yaitu; berwujud (makanan, tampilan menu, dan harga) dan tidak berwujud seperti produk, lingkungan fisik (furnitur, material pembentuk ruang, elemen estetis/dekoratif, pencahayaan, penghawaan \& suara) dan servis (kebersihan, seragam pegawai, pelayan dan jenis peralatan/perlengkapan meja).Suasana restoran yang nyaman, menenangkan, membuat pengunjung merasa betah untuk berlama-lama sehingga kemungkinan untuk membeli lagi dapat menguntungkan pihak tempat makan, sehingga perlu adanya perhatian pada tiap elemen interior restauran. 
Liu dan Jang dalam Wardono menggunakan perpanjangan model Mehrabian dan Russell membuktikan bahwa semua elemen interior lingkungan di restoran baik yang berwujud ataupun tidak, dapat membangkitkan dampak yang signifikan terhadap respon psikologis pengunjung. Berdasarkan pembahasan teori dan penelitian sebelumnya dapat dilihat bahwa lingkungan fisik berupa elemen interior merupakan pengaruh yang penting dalam menciptakan suasana yang dapat mempengaruhi persepsi, emosi dan sikap untuk bernostalgia di tempat makan yang dikunjungi. Dalam proses merespon lingkungan, persepsi merupakan bagian terpenting dalam membantu pembuatan keputusan individu bersikap dan berperilaku. Individu membutuhkan rangsangan ketika mempersepsi lingkungan berupa perasaan menyenangkan, kaitannya dengan salah satu indikasi perasaan nostalgia dapat dipengaruhi oleh elemen dekoratif yang menarik.

Berdasarkan pembahasan yang didasarkan pada teori dan penelitian sebelumnya, terdapat beberapa hal yang dapat digunakan dalam memperkuat dasar penelitian ini. Namun tidak dapat dipungkiri bahwa terdapat pula hal-hal yang belum cukup terjelaskan kaitannya dengan pengaruh elemen interior terhadap pengalaman nostalgia pengunjung. Kepuasaan pengunjung terhadap restoran merupakan kondisi yang harus dipenuhi, karena dapat memberi pengaruh positif terhadap kelangsungan usaha bisnis.

\section{II.3 Metode Penelitian}

Metode yang digunakan dalam penelitian ini adalah eksploratori deskriptif dan eksperimen. Eksploratori dilakukan untuk menggali data dan informasi untuk menemukan hal-hal baru, kemudian dipaparkan secara deskriptif melalui tahapan pra-wawancara dan observasi lapangan kepada masyarakat Medan untuk menentukan restoran dengan suasana tempo dulu yang diusung kembali di era modern saat ini. Hasil tahap prawawancara menunjukkan bahwa Ismud Park, Lekker Urban Food House, Café Tip Top dan Desa-desa resto merupakan lokasi yang cocok sebagai tempat dilaksanakannya tahap wawancara dan kuesioner guna mencari elemen interior apa saja yang dapat membangkitkan perasaan pengunjung.

\section{PEMBAHASAN}

Desain interior tempat makan mencakup seperti, makanan, utilitas, serta desain pada bangunan tersebut. Aneka makanan merupkan beragam sajian yang ditawarkan untuk memenuhi daya tarik terhadap pengunjung. Utilitas pada sebuah bangunan meliputi hal seperti lokasi tempat makan, lapangan parkir, toilet, penghawaan, pencahayaan, penataan ruang, jalur sirkulasi pengunjung (horizontal dan vertical), dan keamanan. Desain interior pada suatu ruang dapat memberikan persepsi visual bagi yang berada didalamnya memalui indra penglihatan dan tanpa disadari desain pada interior suatu ruang dapat mempengaruhi efek psikologis bagi setiap pengunjung. Bermacam desain yang diterapkan pada sebuah ruangan interior tempat makan, akan tetapi pada garis besarnya pada suatu ruangan pasti memiliki garis besar desain yang akan diterapkan. Maka dari itu sebagai perbandingan antar dua desain yang cukup berbeda. Berikut dua tempat makan berbeda yang berlokasi di Kota Medan yaitu Ismud Park, dan Lekker Urban Food House. 


\section{Ismud Park}

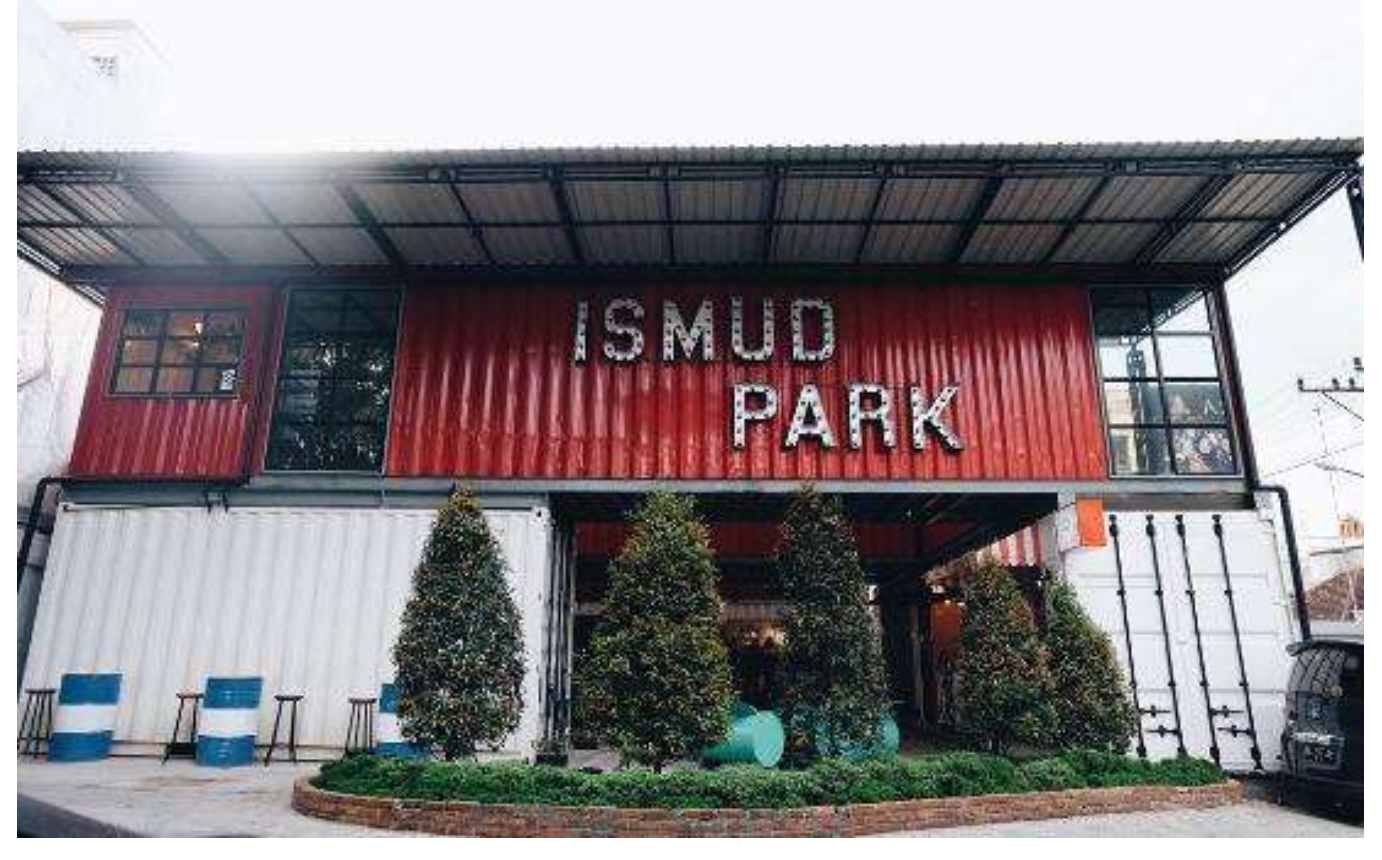

Gambar 2. Foto tampak depan Ismud Park

(Sumber: https://makanmana.net, 2015)

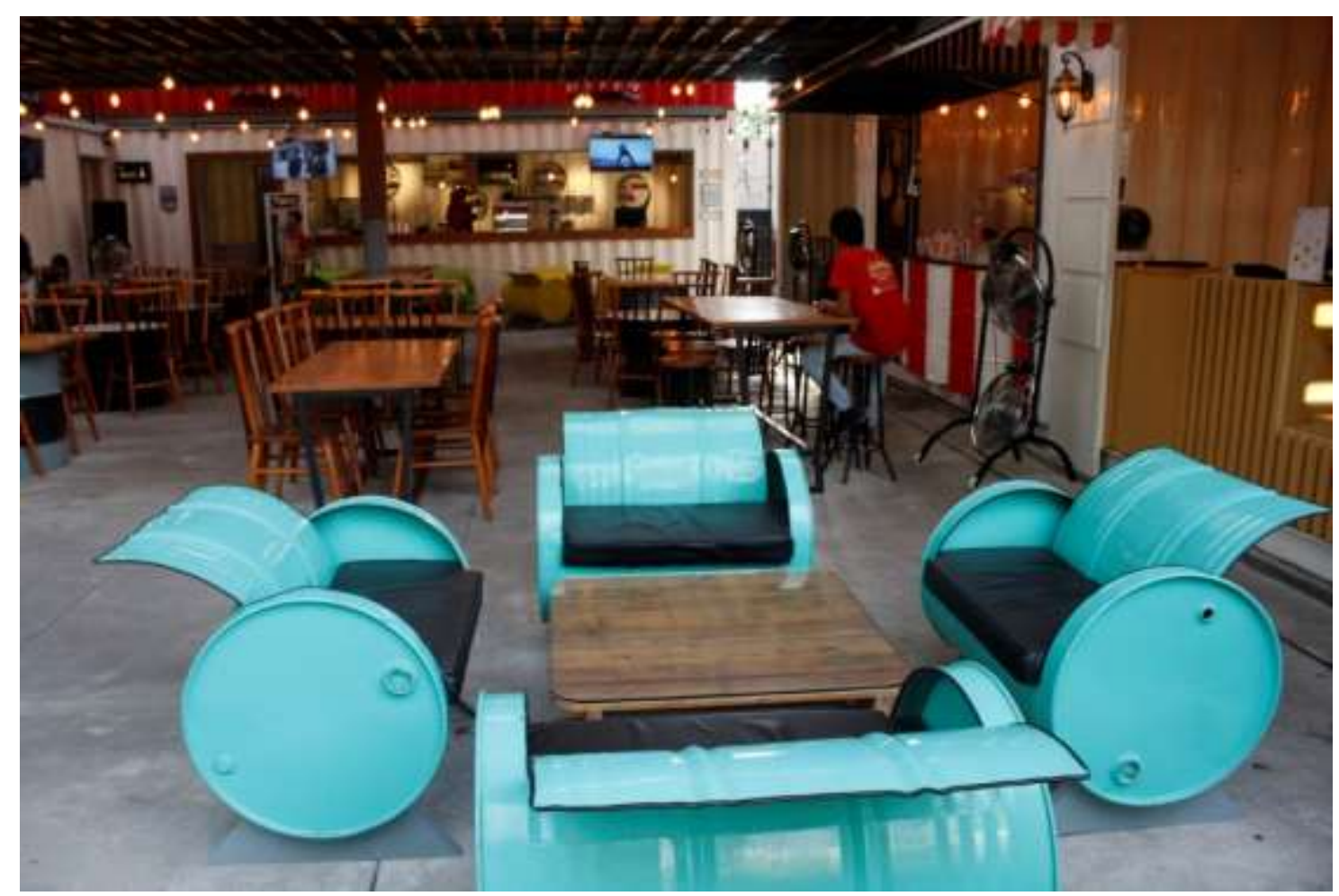

Gambar 3. Foto bagian dalam Ismud Park

(Sumber: http

s://makanmana.net, 2015) 


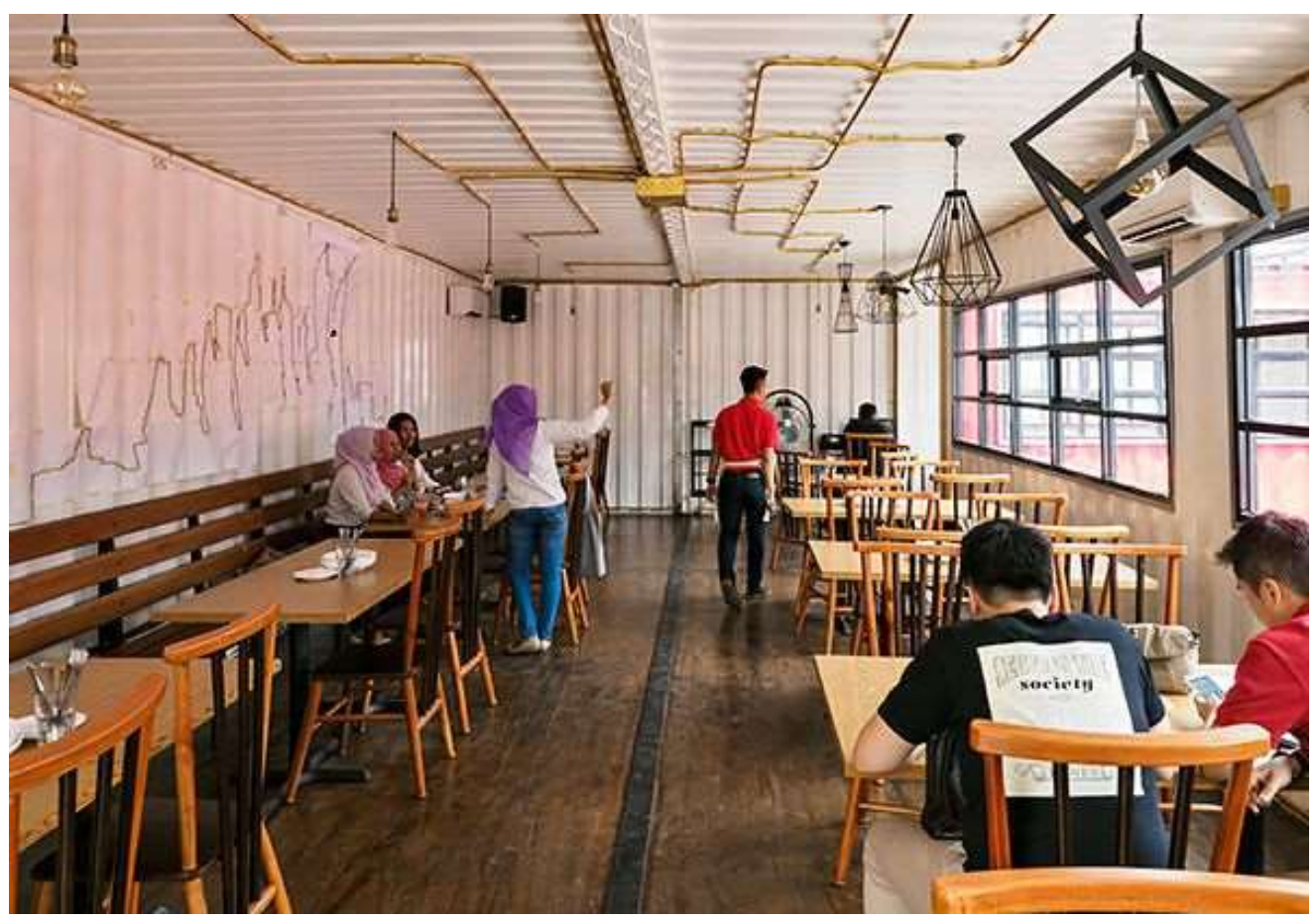

Gambar 4. Foto bagian dalam Ismud Park

(Sumber: https://makanmana.net, 2015)

Ismud Park adalah salah satu tempat nongkrong di Kota Medan yang memiliki keunikan dalam dekorasinya. Mengusung konsep industrial bergaya open air, interior kafe ini terbuat dari beberapa peti kemas atau boxkontainer yang disusun secara rapi dengan dominasi warna merah dan putih. Nama Ismud Park sendiri merupakan singkatan nama jalan di mana kafe ini berada, yakni di Jalan Iskandar Muda No 132, Sei Sikambing D, untuk berkunjung ke tempat makan Ismud Park bisa datang kapan saja, tempat makan tersebut buka selama 24 jam setiap harinya.

\section{Lekker Urban Food House}

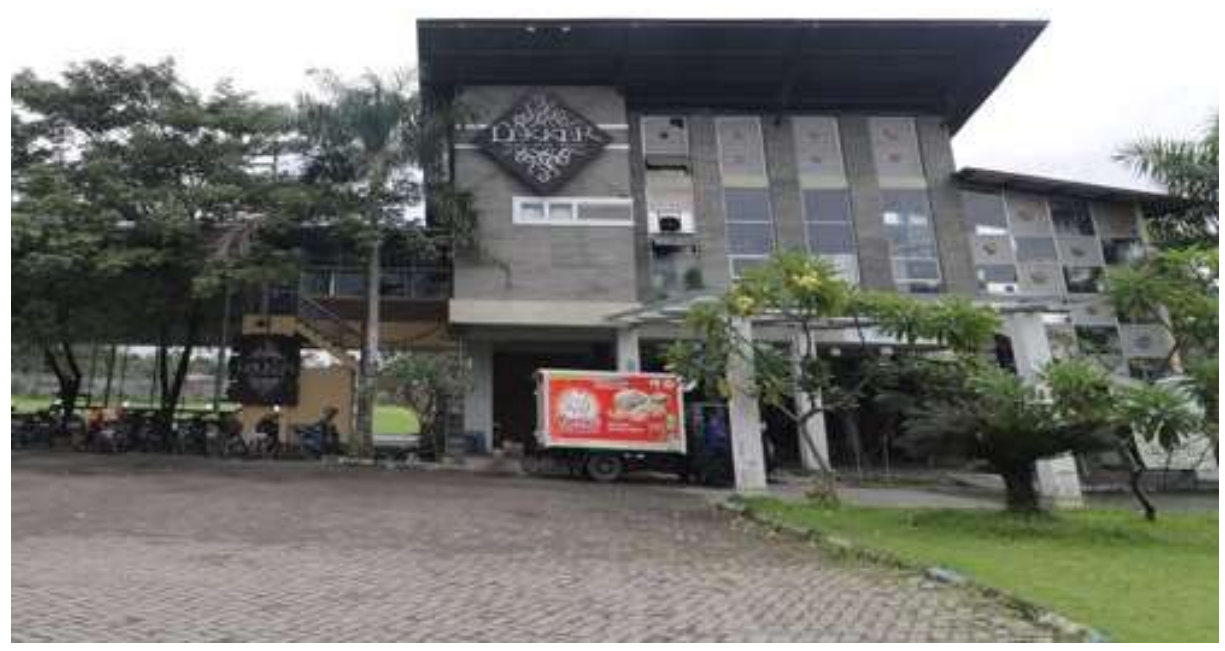

Gambar 5. Foto tampak depan Lekker Urban Food House

(Sumber : Ivo Ramadhani, 2015) 


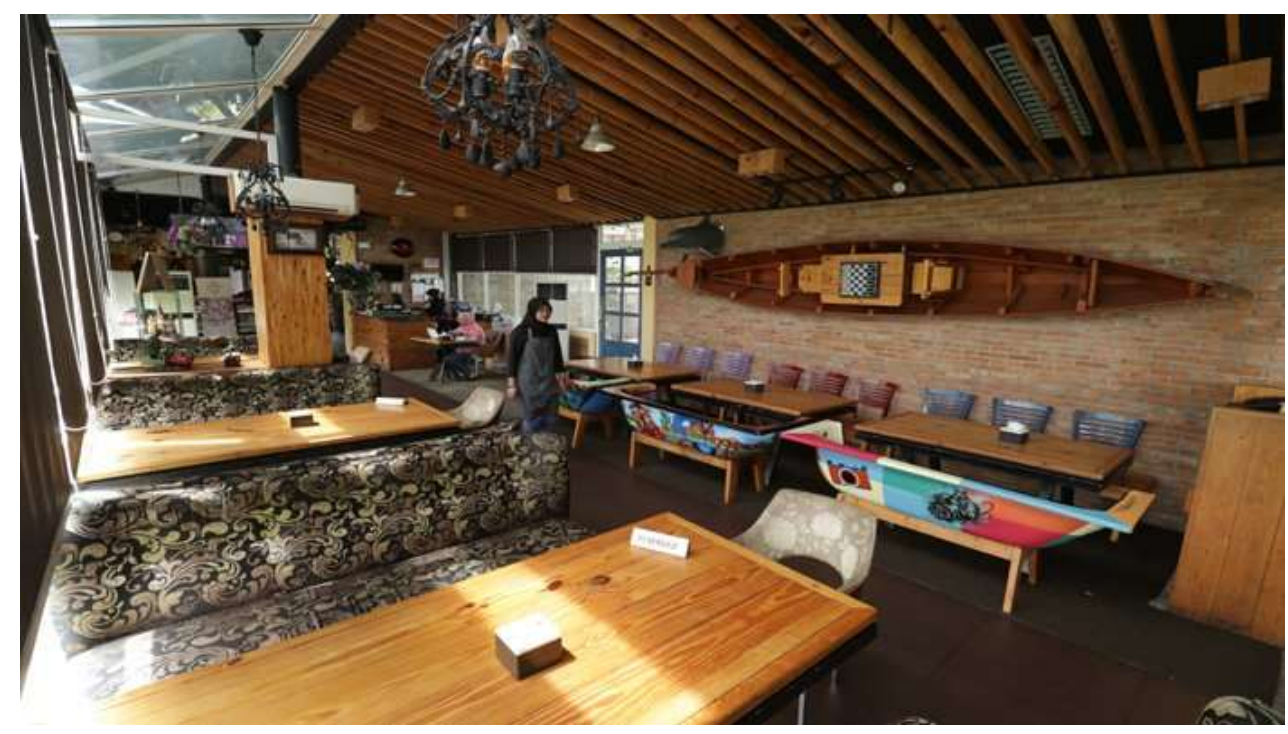

Gambar 6. Foto bagian dalam Lekker Urban Food House

(Sumber : Ivo Ramadhani, 2015)

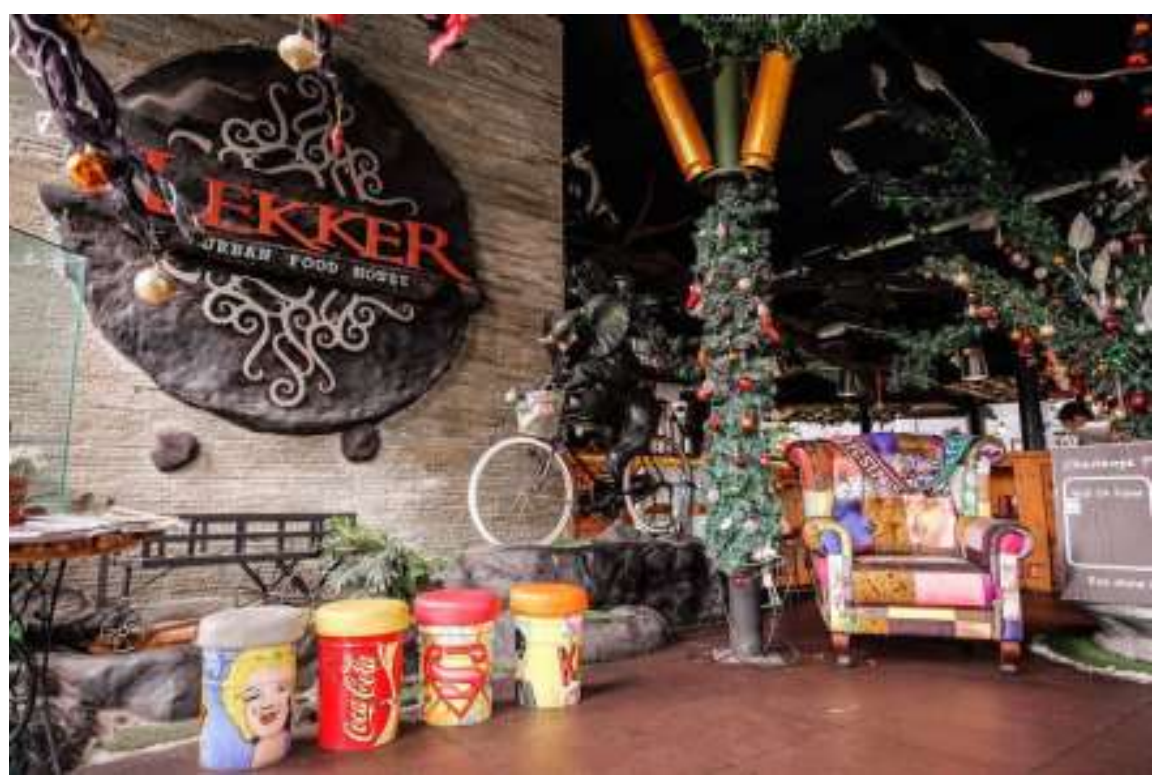

Gambar 7. Foto bagian dalam Lekker Urban Food House

(Sumber : Ivo Ramadhani, 2015)

Lekker Urban Food House terletak di Kompleks Multatuli, Medan. Sepintas dari luar, bangunannya jauh dari kesan luar biasa. Gedungnya dirancang dengan gaya arsitektur minimalis, didominasi warna-warna gelap. Lahan parkirnya cukup luas, dihiasi beragam pepohonan dan rerumputan hijau. Namun semua kesan biasa tersebut akan sirna begitu melangkah masuk kedalam tempat makan. Beragam furnitur dengan warna cerah menghiasi bagian dalam restoran. Beberapa bahkan dibuat dengan bahan unik, seperti kursi yang dibuat dari vespa bekas, bathub bekas, serta drum bekas. Penggunaan material unik tersebut ternyata bukan tanpa alasan. Menurut pengelola Lekker Urban Food House, desainnya memang sengaja dibuat demikian untuk menerapkan prinsip ramah lingkungan. Barangbarang yang digunakan untuk membuat kursi dan meja awalnya dianggap sebagai sampah, namun kemudian bisa menjadi sesuatu yang berguna.

Hasil analisis yang diperoleh dari observasi langsung terhadap pengunjung di dua 
tampat makan tersebut adalah sebagai berikut:

1. Rata - rata pengunjung dari kalangan yang berasal tingkat ekonomi menengah keatas serta lebih dicenderungi oleh remaja.

2. Perilaku sosial yang paling diamati yaitu para remaja, beragam sikap yang dimiliki oleh mereka yang diantaranya seperti ada yang menghormati dari desain yang megah dengan perilaku yang behave, tetapi ada juga yang tidak menyukai desain tempat makan tersebut serta lebih memilih tidak mengunjunginya.

3. Penampilan pengunjung beragam seperti: Cuek, berseragam sekolah, stylish.

4. Aktivitas yang dilakukan yaitu makan, bersosialisasi, berselfie pada spot-spot yang dianggap menarik dan mencari lokasi hotspot sambil bersantai.

Menurut Lamb, dkk (2001) didukung Quinn (1981) terdapat faktor-faktor elemen yang dapat membangun suasana pada sebuah restoran adalah hal-hal:

a. Visual (penglihatan) merupakan unsur yang memiliki kontribusi paling besar dibanding oleh unsur-unsur inderawi yang lain dalam mempersepsi ruang. Meliputi hal-hal yang berkenaan dengan warna, tata cahaya, bentuk dan lain sebagainya. Sebagai contoh, pencahayaan juga memiliki pengaruh dalam suasana restoran (Lamb, Hair,Mc-Daniel, 2001).

b. Auditorial (Suara) Menurut Levy dan Weitz (2001), audio yang dimaksud dis ini adalah keseluruhan alunan suara yang dihadirkan dalam ruanga nuntuk menciptakan kesan rileks baik dari livemusic atau dari perangkat sound system lainnya.

c. Olfaktorial (Aroma)Aroma adalah unsur yang diterima oleh indra penciuman yang juga memiliki peranandalam membentuk suasana ruang secara total.Bau (aroma) yang diterima manusia dapatmenimbulkan perasaan yang menyenangkandan tidak menyenangkan. Kebanyakan orangmenghabiskan waktu dengan suasana hati yanglebih baik bila ada aroma yang sesuai (Karmeladan Junaedi, 2009).

d. Penghawaan atau suhu kondisi penghawaan ruangan mempengaruhi persepsi suasana tiap individu.Suhu ruangan juga merupakan faktor yangmenentukan tingkat kenyamanan penggunaruang (Barry dan Evans, 2004).

e. Taktil atau prabaan, taktil berhubungan dengan indera perabaan, yang bisa merasakan halus ataukasar suatu permukaan. Menurut Quinn(1981), tekstur pada elemen interior dapat membuat perasaan beimajinasi. Persepsi dari kontak tubuh, kenyamanan furniture, dan lain sebagainya berkontribusi terhadap penciptaan atmosfer atau suasana ruang.

\section{KESIMPULAN}

Kombinasi dari Elemen interior pada tempat-tempat makan mampu menampilkan sesuatu yang berbeda, dengan mampu menawarkan beragam atmosfer sehingga mampu mengajak pengunjung untuk bisa memberikan alternatif suasana bersantap yang berbeda dari biasanya. Atmosfer yang terbentuk diperkuat dengan kesatuan antar elemen, mulai dari elemen pembentuk ruang, pelengkap pembentuk ruang, utilitas, fasilitas sampai dekorasi. Kesatuan tersebut dapat menciptakan ambience yang dapat langsung dirasakan dengan mudah oleh pengunjung. Perpaduan antara atmosfer ruang yang diciptakan oleh elemen desain interior dan menu yang lezat menjadi dua hal yang ditawarkan tempat makan ini sebagai strategi marketing yang diharapkan mampu member dampak positif bagi profit tempat makan

Elemen yang terdapat pada berbagai tempat makan dapat mempengaruhi desain daripada arsitektural dan interior tempat makan tersebut, desain arsitektural dan interior 
mengacu pada sosial masyarakat. Sebagian kalangan yang bukan dari kalangan atas dapat merasa terintimidasi oleh desain interior yang diperuntukkan kepada masyarakat ekonomi tinggi. Sehingga masyarakat dari kalangan bawah memilih untuk tidak mengunjungi tempat makan tersebut, dan sebaliknya oleh para remaja di Kota Medan dengan lifestyle hedon serta ekonomi tinggi akan menghindari tempat makan yang diperuntukkan kalangan ekonomi rendah karena dianggap menjatuhkan status sosial. Dengan demikian secara menyeluruh desain interior yang terdapat pada suatu tempat makan akan otomatis pula mempengaruhi sosial masyarakat, gaya hidup, dan penampilan.

\section{SARAN}

Seorang desainer diwajibkan untuk menyisipkan nilai-nilai kebudayaan dalam mendesain ruang tempat makan guna mensosialisasikan kebudayaan dari setiap daerah, dan membuat kalimat didalam frame maupun mural yang berisi petuah agar tetap menjadi orang yang sederhana tanpa mempengaruhi status sosial, dan dalam memilih elemen-elemen interior desainer harus dapat menampilkan suasana hangat dan tenang agar konsumen yang datang dapat menikmati suasana ketika masuk ke dalam ruangan tempat makan.

\section{DAFTAR PUSTAKA}

\section{Jurnal :}

[1] Quigley, S.R. Pengaruh Interior Mall Terhadap Kehidupan Sosial, Gaya Hidup, dan Penampilan Remaja. Program Studi Sarjana Desain Interior, Fakultas Seni Rupa dan Desain. Bandung: Institut Teknologi Bandung.

[2] S.P, Fhery. 2008. Pengaruh Aspek Sosial Budaya Pada Desain Interior Hotel Niagara Di Lawang. Jurusan Desai Interior, Fakultas Seni dan Desain, Universitas Kristen Petra Surabaya.

[3] S.R., Miranti, dkk. 2017.Pengaruh Elemen nterior Restoran Terhadap Pengalaman Nostalgio Konsumen. Program Studi Magister Seni Rupa, Fakultas Seni Rupa dan Desain, Institut Teknologi Bandung,Bandung.

[4] Nugroho, Eko. 2008. Pengenalan Teori Warna. Jakarta: Andi Publishers

\section{Website:}

[1] Saputri, Andi. 2015. "Proses Persepsi". [cited: 2015 Maret,1]. Available from :https://andisaputri26.wordpress.com/2015/03/19/proses-persepsi/

[2] Sutanujaja, Elisa. 2001, 7 Maret. "Desain Interior dan Ekonomi Kota”. [diakses: 2015 juni]. Available from http://repository.usu.ac.id/bitstream/123456789/39392/6.pdf

[3] Utama, David. 2010, 9 Desember. “Atmosfer Ruang”. [diakses: 2015 juni]. Available from : http://repository.usu.ac.id/handle/123456789/39392

[4] "Pengaruh Interior Restoran The Kiosk Balubur Town Square Terhadap Perilaku Pengunjung”. [diakses: 2015 juni]. Available from :http://www.academia.edu/13299351/ 
[5]Pengaruh_Interior_Restoran_The_Kiosk_Balubur_Town_Square_Terhadap_Perilaku_P engunjung

[6] https://makanmana.net/2015/11/19/ismud-park-cafep-marketplace/ 